\title{
Study of the Influence Factors of the Attraction of FDI in the Economy of the Recipient State - Example of Russia
}

\author{
Stefaniya Tsoneva ${ }^{1}$ \\ ${ }^{1}$ School of Economics, Shanghai University, People`s Republic of China \\ Correspondence: Stefaniya Tsoneva, School of Economics, Shanghai University, People`s Republic of China. \\ E-mail: stefaniya.tsoneva@yahoo.com
}

Received: May 18, 2020

doi:10.5539/ijef.v12n8p101
Accepted: July 10, 2020

Online Published: July 15, 2020

\begin{abstract}
This article focuses on the formation of new scientific decisions regarding the study of factors that influence the attraction of FDI in the economy of the host state using Russia as an example. The study focuses on the need for stimulation of FDI in the Russian economic system so as to overcome the recession and the impact of economic sanctions. Based on the analysis of the dynamics of FDI per capita, inflows, outflows, FDI balances in Russia, as well as a three-year forecast, a conclusion about the critical state of attracting such investments to the economy of the recipient country is made. Separately, on the basis of critical literary analysis, the concept of identifying the factors influencing the attraction of FDI in the host economy is selected, and seventeen of the main factors of such influence for the Russian Federation are identified. Based on a quantitative analysis of the identified factors influencing the attraction of FDI in the Russian economy, the directions of their influence (positive or negative) are identified. It is noted that only three of the selected influence factors have a positive effect on attracting FDI into the economy of the Russian Federation and ten identified factors have a negative effect, which is a critically negative aspect for the host state selected for research within the framework of its competitiveness in the market of investment resources. It is indicated that Russia needs to change the strategy for attracting FDI into the national economic system based on the development and implementation of a set of long-term measures. Also, based on the use of a comparative assessment, significant differences between the factors influencing the attraction of FDI in developed and developing countries is proved.
\end{abstract}

Keywords: FDI, host economy, influence factors, recipient country

\section{Introduction}

The development of the modern national economic system is based on attracting FDI (Solomon, 2011; Maza \& Villaverde, 2015). FDI is important, especially for the developing countries, given their significant economic and social problems, as well as a considerable deficit in domestic investment (Buthe \& Milner, 2008; Amal, Tomio, \& Raboch, 2010; Galenkova, Mariev, \& Chukavina, 2018). At the same time, the volume of FDI, despite their overall long-term growth (UNCTAD, 2020) fluctuates significantly: for specific time periods, regions of investments, investment countries, areas of investment. This situation gives rise to a significant competition, which attracts FDI between recipient countries, especially with regard to developing countries and countries with economies in transition (including Russia) (Tintin, 2013; Gokalp \& Yildirim, 2016; Gorbunova, 2018).

The competition for attracting FDI between the host economies leads to the search for ways of attracting FDI, where the study of the factors influencing the attraction of FDI takes a special place. We note significant interest in this type of research from scientists (Azzimonti \& Sarte, 2007; Makoni, 2014; Shchetinina \& Hamdan, 2018) and international organizations (UNCTAD, 2020; The World Bank, 2020).

In these circumstances, it is of great interest to identify and evaluate the impact of the factors attracting FDI in the economy of the Russian Federation. This interest is based on three main points:

- Russia's economy is one of the largest in the world and among the economies of developing countries, as well as countries with economies in transition;

- Any actions of the Russian Federation of attracting FDI have a significant impact on the global market for investment resources;

- The country's economy is in a recession and under the influence of economic sanctions, which requires a 
change in the strategy of attracting FDI.

We note significant problems in the Russian economy and negative trends in attracting FDI (Drapkin, Mariev, \& Chukavina, 2015; Kvashnina, 2015). In these conditions, the country needs to identify and localize the influence of negative factors, as well as stimulate the influence of positive factors regarding the attraction of FDI.

The above allows us to formulate the purpose of the scientific work as a study of the factors influencing the attraction of FDI in the economy of the Russian Federation in the context of the formation of a real picture regarding their structure, as well as the ultimate sign of influence on the host economic system.

As part of the achievement of the research goal, it is necessary to confirm or refute some hypotheses:

- In the context of identifying factors influencing the attraction of FDI in the economy of the recipient country, it is necessary to rely on the representation of the largest possible group of factors in order to cover all the key ones;

- A description of the factors influencing the attraction of FDI in the economy of the Russian Federation allows us to state factors of positive influence prevail;

- The presence of significant differences between the factors influencing the attraction of FDI in developed and developing countries;

- FDI inflows into the Russian economy demonstrate predominantly positive dynamics.

\section{Literature Review}

In the study, we first consider the theoretical foundations of the influence of factors on attracting FDI in the host state, and then study the key influence factors on attracting FDI to Russia.

\subsection{Identification of Factors Influencing the Attraction of FDI in the Economy of the Recipient Country}

Given the constant growth in demand for FDI and stiff competition for their attraction, especially between developing countries (Buthe \& Milner, 2008; Amal, Tomio, \& Raboch, 2010; Tintin, 2013; Gokalp \& Yildirim, 2016), it is of particular importance to identify factors that can be both an additional incentive for the influx of FDI into the country, and significant barriers increasing their size in the national economy. Noting significant attention to the problem of identifying factors influencing the attraction of FDI in the economy of the recipient country, from foreign and Russian scientists (Tobin \& Rose-Ackerman, 2005; Mohamed, Bruno, \& Henrique, 2010; Solomon, 2011; Makoni, 2014; Maza \& Villaverde, 2015), as well as Russian scientists (Goblik \& Feer, 2016; Bandurka, Nosova, \& Nosova; 2016; Galenkova, Mariev, \& Chukavina, 2018).

Summing up the assessment of scientific developments about the factors influencing the attraction of FDI in the economy of the host countries, three groups of such studies should be distinguished:

- Emphasis on highlighting one key influencing factor, from a scientist's point of view;

- The allocation of a small group of main influencing factors;

- Representation of the largest possible group of factors in order to cover all key ones.

Regarding the first group of scientific studies, it should be noted that scientists justify the presence of only one factor influencing the attraction of FDI in the economy of the recipient country from the point of view that all other factors are either included in the proposed key factor or are of secondary importance, and may not be taken into account in the framework of modeling, as well as empirical analysis. In table 1, we carry out a literary critical analysis of scientific developments that focus on one factor influencing the attraction of FDI in the economy of the recipient country.

Table 1. Literary critical analysis of scientific research attracting FDI into the economy of the recipient country based on the identification of one influence factor

\begin{tabular}{ccc}
\hline Scientist & Influence factor & Critical analysis \\
\hline Buchanan, Le, Rishi, 2012 & Institutional environment & $\begin{array}{l}\text { The most important factor for developing countries, but secondary for } \\
\text { developed ones. Political, economic, international influence factors are not } \\
\text { taken into account. }\end{array}$ \\
Buthe, Milner, 2008 & Participation in & $\begin{array}{l}\text { Risk reduction for foreign investors in developing countries. Political, } \\
\text { Azzimonti, Sarte, } 2007\end{array}$ \\
& Political instability & $\begin{array}{l}\text { Acceptable for both developed and developing countries. Economic, } \\
\text { international and institutional influence factors are not taken into account. }\end{array}$ \\
\hline
\end{tabular}


Tobin, Rose-Ackerman, 2005

Koboekae, 2012

Schneider, Frey, 1985

Busse, Hefeker, Nelgen, 2013;

Bilawal, Ibrahim, Abbas, Shuaib,

Ahmed, Hussain, Tehreem, 2014
Bilateral investment Risk reduction for foreign investors in developed and developing countries.

agreements between the Political, economic, institutional influence factors are not taken into account. countries

Political risks

It is characteristic of developed and developing countries. Economic, international and institutional influence factors are not taken into account. Risk reduction for foreign investors in developing countries. Political, other economic, institutional and international influence factors are not taken into account.

Exchange rate

Characteristic for developing countries. Political, other economic, institutional and international influence factors are not taken into account.

Source: developed by the author.

Considering the scientific approach above, it is necessary to highlight its positive and negative aspects in terms of theory and practice. The positive aspects include: the simplicity of explaining the situation in attracting FDI into the economy of the host state; the opportunity to develop a set of measures to optimize the impact of the identified factor on attracting FDI to the country; saving resources for analyzing the impact and forecasting changes from the developed optimization measures. The negative aspects of such a scientific approach are: the difficulty of identifying only one factor influencing the inflow of FDI into the state economy; the presence of a significant influence on attracting FDI in the country's economy - a recipient of other factors that may not be taken into account, which critically reduces the practical value of scientific developments.

A significant number of scientists, taking into account the negative aspects of the first scientific approach, as part of their scientific work, highlight a limited number of main factors influencing the attraction of FDI in the economy of the recipient country, noting that these factors shape the size and dynamics of FDI inflows to the host countries. In table 2, we carry out a literary critical analysis of scientific developments, which focuses on several main factors influencing the attraction of FDI in the economy of the recipient country.

Table 2. Literary critical analysis of scientific research on attracting FDI in the economy of the recipient country based on the allocation of a limited number of main influence factors

\begin{tabular}{|c|c|c|}
\hline Scientist & Influence factors & Critical analysis \\
\hline $\begin{array}{l}\text { Asiedu, Esfahani, } \\
1998\end{array}$ & $\begin{array}{l}\text { Government policy, institutional infrastructure, size } \\
\text { of ownership in host country projects. }\end{array}$ & $\begin{array}{l}\text { More characteristic for developing countries. Do not take into } \\
\text { account economic and international factors of influence. }\end{array}$ \\
\hline $\begin{array}{l}\text { Amal, Tomio, } \\
\text { Raboch, } 2010\end{array}$ & $\begin{array}{l}\text { Economic stability, growth and openness of trade, } \\
\text { institutional environment, political environment. }\end{array}$ & $\begin{array}{l}\text { More characteristic for developing countries. International } \\
\text { factors of influence are not taken into account. }\end{array}$ \\
\hline Brainard, 1997 & $\begin{array}{l}\text { The size of the donor country, the recipient } \\
\text { country, as well as the distance between countries. }\end{array}$ & $\begin{array}{l}\text { It is possible to apply for developed and developing countries. } \\
\text { Political, economic, institutional and international factors of } \\
\text { influence are not taken into account. }\end{array}$ \\
\hline Fan, 2009 & $\begin{array}{l}\text { Government image, stable economic growth, } \\
\text { quality work of government institutions. }\end{array}$ & $\begin{array}{l}\text { Characteristic for developing countries. International factors } \\
\text { of influence are not taken into account. Political, economic, } \\
\text { and institutional factors of influence are poorly disclosed. }\end{array}$ \\
\hline $\begin{array}{l}\text { Maza, Villaverde, } \\
2015\end{array}$ & $\begin{array}{l}\text { Economic potential, labor market characteristics, } \\
\text { technological progress and regional } \\
\text { competitiveness }\end{array}$ & $\begin{array}{l}\text { Characteristic for developed and developing countries. } \\
\text { Political and international factors of influence are not taken } \\
\text { into account. }\end{array}$ \\
\hline Luzgina, 2016 & $\begin{array}{l}\text { Institutional environment, the development of the } \\
\text { national economic system. }\end{array}$ & $\begin{array}{l}\text { Characteristic for developing countries. Political and } \\
\text { international factors of influence are not taken into account. }\end{array}$ \\
\hline $\begin{array}{l}\text { Shchetinina and } \\
\text { Hamdan, } 2018\end{array}$ & Political, economic, legal and administrative. & $\begin{array}{l}\text { More characteristic for developing countries. Institutional and } \\
\text { international factors of influence are not taken into account. }\end{array}$ \\
\hline
\end{tabular}

Source: developed by the author.

Considering the scientific approach above, it is necessary to highlight its positive and negative sides, theoretically and practically. The positive aspects include: the ability to disclose and identify key incentives, as well as barriers to attracting FDI in the host economy; the possibility of developing a strategy (strategy adjustment) to attract FDI in the national economy; the relative simplicity and low complexity of monitoring and evaluation of identified factors of influence. The negative sides of such scientific approach are: the complexity of the distribution of factors of influence on the main and secondary; the ability to not take into account the 
dynamics of the change in the factor of influence from the main to the secondary and vice versa; significant subjectivity of the distribution of influence factors; increased resource costs for managing the factors of attracting FDI in the host economy.

Practical problems regarding the allocation and consideration of one or more key factors influencing the attraction of FDI in the economy of the recipient country have led to the appearance of scientific developments based on the allocation of the largest possible group of influence factors. In table 3 , we carry out a literary critical analysis of scientific developments, which focus on an extensive range of the main factors influencing the attraction of FDI in the economy of the recipient country.

Table 3. Literary critical analysis of scientific research on attracting FDI to the economy of the recipient country based on the allocation of the maximum number of main influence factors

\begin{tabular}{|c|c|c|}
\hline Scientist & Influence factors & Critical analysis \\
\hline $\begin{array}{l}\text { Drapkin, Mariev, } \\
\text { Chukavina, } 2015\end{array}$ & $\begin{array}{l}\text { The size of the country and the distance between the donor } \\
\text { country and the recipient country, the openness of the recipient } \\
\text { country economy, the level of remuneration in the recipient } \\
\text { country, resistance for the donor country and the recipient } \\
\text { country, common language, the presence of colonial ties. }\end{array}$ & $\begin{array}{l}\text { Typical for developing countries. Political and } \\
\text { international influence factors are not taken } \\
\text { into account }\end{array}$ \\
\hline Dang, 2016 & $\begin{array}{l}\text { External (integration and globalization, political and natural } \\
\text { disasters), as well as internal (economic, labor and natural } \\
\text { resources, an open economy) factors }\end{array}$ & $\begin{array}{l}\text { Typical for developing countries. The logic of } \\
\text { choosing a factor of influence is not always } \\
\text { clear. Institutional and international factors of } \\
\text { influence are not taken into account. }\end{array}$ \\
\hline Goblik, Feer, 2016 & $\begin{array}{l}\text { Market size, openness to foreign trade, financial development, } \\
\text { government spending, international money transfers, } \\
\text { agglomeration, natural resources. }\end{array}$ & $\begin{array}{l}\text { Typical for developed and developing } \\
\text { countries. The focus is only on economic } \\
\text { factors that require to be detailed. }\end{array}$ \\
\hline Gorbunova, 2018 & $\begin{array}{l}\text { Economic, legal, institutional, international, political } \\
\text { (sanctions) }\end{array}$ & $\begin{array}{l}\text { Typical for developing countries to which } \\
\text { international sanctions have been applied. }\end{array}$ \\
\hline Demchenko, 2011 & $\begin{array}{l}\text { Legislation, tax system, privatization efficiency, foreign } \\
\text { economic openness of the country, administrative pressure, } \\
\text { bureaucracy, formation of investment plans. }\end{array}$ & $\begin{array}{l}\text { Typical for developing countries. The logic of } \\
\text { choosing a factor of influence is not always } \\
\text { clear. International factors of influence are not } \\
\text { taken into account. }\end{array}$ \\
\hline Tretyak, 2013 & $\begin{array}{l}\text { Organizational - legal, political, economic, country potential, } \\
\text { financial, socio-cultural, international relations, economic } \\
\text { development, general economic conditions. }\end{array}$ & $\begin{array}{l}\text { Typical for developed and developing } \\
\text { countries. Institutional factors of influence are } \\
\text { not taken into account. Requires to be } \\
\text { detailed. }\end{array}$ \\
\hline $\begin{array}{l}\text { Galenkova, Mariev, } \\
\text { Chukavina } 2018\end{array}$ & $\begin{array}{l}\text { FDI, GDP growth, GDP deflator, number of Internet users per } \\
100 \text {, unemployment rate, trade openness index, percentage of } \\
\text { the population with higher education, high-tech export share. }\end{array}$ & $\begin{array}{l}\text { Typical for developed and developing } \\
\text { countries. International factors of influence } \\
\text { are not taken into account. }\end{array}$ \\
\hline
\end{tabular}

Source: developed by the author.

Considering the scientific approach above, it is necessary to highlight its positive and negative aspects in terms of theory and practice. The positive aspects include: maximum coverage of influence factors attracting FDI in the economy of the recipient country; low probability not taking into account in modeling and forecasting the key factor in the impact of FDI on the host economy; the possibility of developing and adjusting the strategy of attracting FDI in the country, relying on a large array of objective information, as well as statistical data. The negative aspects of this scientific approach are: the difficulty of determining sufficient and not excessive for practical purposes, attracting FDI in the country's economy - the recipient of the number of influence factors; increasing the complexity and cost of resources regarding monitoring, as well as assessing the impact of identified factors on the host national economic system; increasing the complexity of managerial influences.

Summing up the study, we can agree with a number of scientists such as (Fabry \& Zeghni, 2006; Melnyk, Kubatko, \& Pysarenko, 2014; Dang, 2016) that the third scientific approach is more appropriate based on practical tasks, attracting FDI into the economies of recipient countries, especially, as for states with developing and transitional economic systems, to which we include the Russian Federation. Under such conditions, it is important to single out and characterize the factors involved in attracting FDI into the Russian economy, based on the above data and the proposed methods. 


\subsection{Theoretical Problems of Identifying the Factors Influencing the FDI Attraction in the Economy of the Russian Federation}

Despite the presence of a significant amount of scientific research on the problem of attracting FDI in the economy of recipient countries (Buthe \& Milner, 2008; Amal, Tomio, \& Raboch, 2010; Maza \&Villaverde, 2015), we note a significant shortcoming regarding the identification of factors influencing the attraction FDI in the Russian economic system, which requires further research. Moreover, foreign scientists (Lipsey, 2002; Tobin \& Rose-Ackerman, 2005; Solomon, 2011; Melnyk, Kubatko, \& Pysarenko, 2014) either do not address such problems specifically to Russia, or consider them in general, together with other countries around the world (developing countries, countries with economies in transition, recipient countries, countries of Central and Eastern Europe, countries of Eastern Europe, post-communist countries or countries that were part of the Soviet Union). Russian scientists are more focused on solving certain problems of attracting FDI into the Russian economy, without paying attention to identify all the key factors affecting the attraction of FDI in the Russian economic system (Sergeev \& Veretennikova, 2000; Kvashnina, 2015; Gorbunova, 2018). Thus, we can argue that there is a significant theoretical problem regarding the identification of factors influencing the attraction of FDI in the economy of the Russian Federation, which requires further research

\section{Materials and Methods}

To conduct the study, quantitative data analysis on the dynamics of FDI is used, as well as the main factors influencing their inflow into the Russian economy over the last twenty years (1999-2018 years) using onedimensional statistical methods. Time series analysis based on the use of regression functions is used for the forecasting:

- linear:

$$
y=b_{0}+b_{1} x
$$

-logarithmic:

$$
y=b_{0}+b_{1} \ln (x)
$$

- polynomial:

$$
y=b_{0}+b_{1} x+b_{2} x^{2}
$$

In this case, a three-year forecast of the FDI balance in the economy of the Russian Federation is formed using Stata 7.0, where the criterion for the selection of the function and the characteristic of its adequacy is the determination coefficient $\left(\mathrm{R}^{2}\right)$. To solve the problem of selecting the concept of identifying factors influencing the FDI inflows into the economies of recipient countries is used a literary analysis. The comparative assessment method is applied separately to identify the differences between the factors attracting FDI in the economies of developed and developing countries.

The research methodology is based on a historical and systematic approach, where a historical approach is used to assess individual factors influencing FDI inflows into the Russian economy over twenty years, and a systematic approach allows us to consider the whole set of factors influencing the attraction of FDI in the Russian economic system, as well as their relationship.

The study is based on statistical and other data on the development of the Russian economy, and the attraction of FDI in the Russian Federation for the period between 1999-2018 years. Moreover, statistical information is taken from the databases of the Federal State Statistics Service of the Russian Federation, Knoema, The World Bank, Heritage Foundation, The Fund for Peace, The World Economic Forum, and the Central Bank of the Russian Federation.

\section{Results}

4.1 Characterization of Factors Influencing the Attraction of FDI in the Economy of the Recipient Country on the Example of the Russian Federation

Considering the research as well as the features of the development of the economic system of the Russian Federation, as a developing state, we consider it appropriate to identify the following seventeen factors influencing the attraction of FDI in the country's economy:

1). Economic factors: GDPg - GDP growth rate; Defl - GDP deflator; Unempl - unemployment rate; RD (R) NC - the rate of devaluation (revaluation) of the national currency (in our case, the Russian ruble); GRIRCI - the growth rate of interest rates on capital investments (interest rates on deposits with banks); BTB - business tax burden level; LLP - the level of labor productivity; 
2). Political factors: inst - the product of the indices of economic freedom and state insolvency;

3). Institutional factors: IntUs - the number of Internet users per 100; LFTE - the percentage of the population with higher education;

4). International factors: TOI - trade openness index; HTE - the share of high-tech exports in total exports; DB country rating according to the level of business conditions; GC - the country's global competitiveness index; GRFDI - the country's global ranking in terms of FDI; DBIRIri - the difference between the interest rates on investments in Russia and international interest rates; DBPIri - the difference between the price of investments in Russia and international prices

We note that the emphasis in highlighting the factors influencing the attraction of FDI in the Russian economy is made on economic and international ones, while political and institutional ones are not widely represented. The reason for this situation is that international ratings are actively used as factors influencing the attraction of FDI into the economic system, which comprehensively reflect, including political and institutional factors. The "inst" factor is related to political factors because the political situation in developing countries determines the economic freedom and insolvency of the state as a business partner in relation to its counter parties.

We consider it appropriate to characterize the identified factors influencing FDI in the Russian economy and track their dynamics over the selected study period (1999-2018).

The growth rate of GDP (GDPg) is one of the main factors influencing the attraction of FDI in the state economy since the economic situation in the country that characterizes this factor is important for foreign investors. High GDP growth rates often indicate an economic recovery and are a good opportunity to ensure a high return on investment. Low GDP growth rates indicate the accumulation of problems in the national economy and require special attention for companies-investors; at the same time, it is possible to capture a large share of the national market due to significant investments. The absence of growth or a decrease in GDP indicates a stagnation or crisis in the national economic system; this situation is good for investments aimed at creating export supplies due to the cheapness of resources; foreign investors oriented to the national market reduce or withdraw investment. Based on the above, we consider the dynamics of the Russian Federation GDP growth rate for the selected study period (Fig. 1).

We note that to calculate the growth rate of Russia's GDP, statistical data in USD were taken to remove the effect of devaluation (revaluation) of the national currency on the obtained values.

Assessing the dynamics of the GDP growth rate in the Russian Federation, we note that the period from 1999 to 2008 was the most optimal for attracting FDI. The period from 2009 to 2011 was characterized by economic problems associated with the impact of the global economic crisis on the national economic system and its postcrisis recovery. The period from 2012 to 2018 was critically unfavorable for attracting FDI due to economic problems and the economic crisis, which occurred against the background of the application of economic sanctions against the country. We note the unfavorable current economic situation in Russia in the context of attracting FDI, which is exacerbated by the economic sanctions that apply to the country.

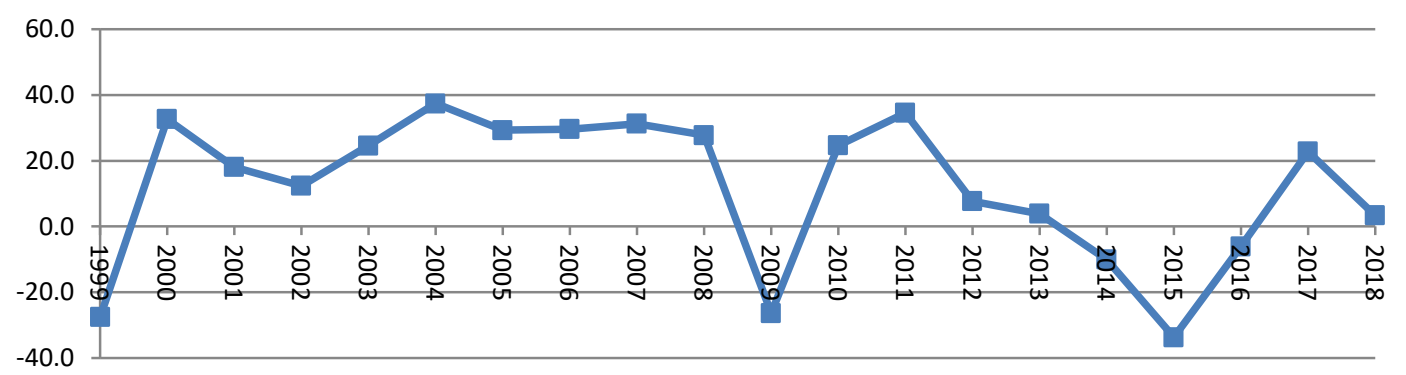

Figure 1. The dynamics of the GDP growth rate of the Russian Federation for 1999-2018, \% (to the previous year)

Note. Compiled by the author based on: [Federal State Statistics Service of the Russian Federation, 2020].

The Trade Openness Index (TOI), calculated by the World Bank, makes it possible to assess the level of barriers and closure of the national economy from foreign companies. In the short term, the closure of the national economy provides support to national producers. In the long run, it leads to a negative impact on their development and reduces the rate of economic growth in the country. The low level of trade openness reduces 
the interest of foreign investors in FDI, as it leads to additional transaction costs while overcoming trade barriers. Given the above, let us consider the dynamics of the Russian trade openness index for the study period (Fig. 2).

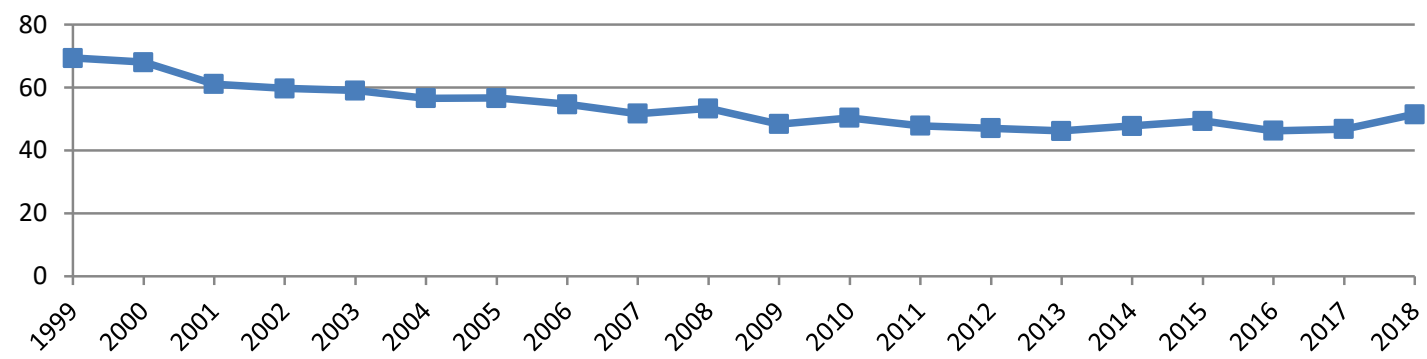

Figure 2. Dynamics of the Russian Federation trade openness index for 1999-2018

Note. Compiled by the author based on sources: [The World Bank, 2020].

We note a constant negative trend of a decrease in the trade openness index in Russia over the study period with slight positive changes in the short-term periods. It can be concluded that the Russian Federation is continually increasing trade barriers in order to stimulate the development of domestic producers, which, given the pace of GDP growth (see Fig. 1), does not bring proper results. This situation is a negative factor in attracting FDI.

The GDP deflator (Defl) allows us to evaluate the impact of prices on the country's economic system. We note the problems for the state economy with high values of the GDP deflator, which causes particular attention of foreign investors and is a negative factor in attracting FDI to the economic system of the recipient state. At the same time, low values of the GDP deflator often indicate a stagnation of the country's economy or crisis, which leads to an FDI outflow. We are considering the dynamics of the GDP deflator for the Russian Federation in (Fig. 3).

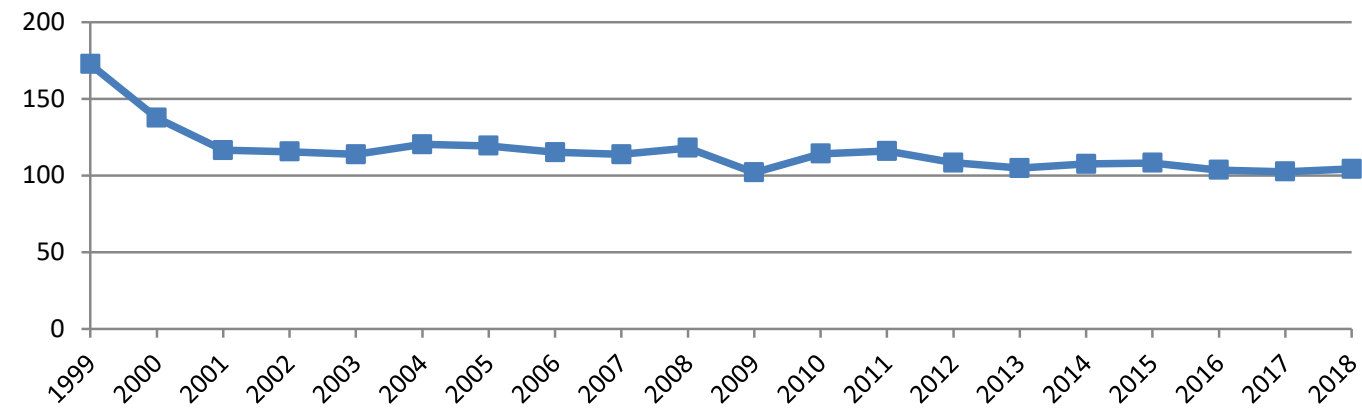

Figure 3. Dynamics of the GDP deflator of the Russian Federation for 1999-2018, \%

Note. Compiled by the author based on sources: [Federal State Statistics Service of the Russian Federation, 2020].

Assessing the changes in the GDP deflator of the Russian Federation over the study period, we note its negative dynamics, which clearly repeats the crisis in the Russian economy. The above assessment indicates that the current state of the Russian economic system is not favorable for attracting FDI.

An important component of the country's institutional environment and evidence of the development of its information infrastructure is the number of Internet users per 100 people (IntUs). The modern information economy depends on the development of Internet technologies and access to them by residents of the country. Thus, the increase in the number of internet users per 100 people or its large values is evidence of the development of the institutional environment and infrastructure of the state and is a good sign for foreign investors, including regarding the investment of FDI. We are considering the dynamics of the share of internet users per 100 people in Russia over the study period (Fig. 4). 


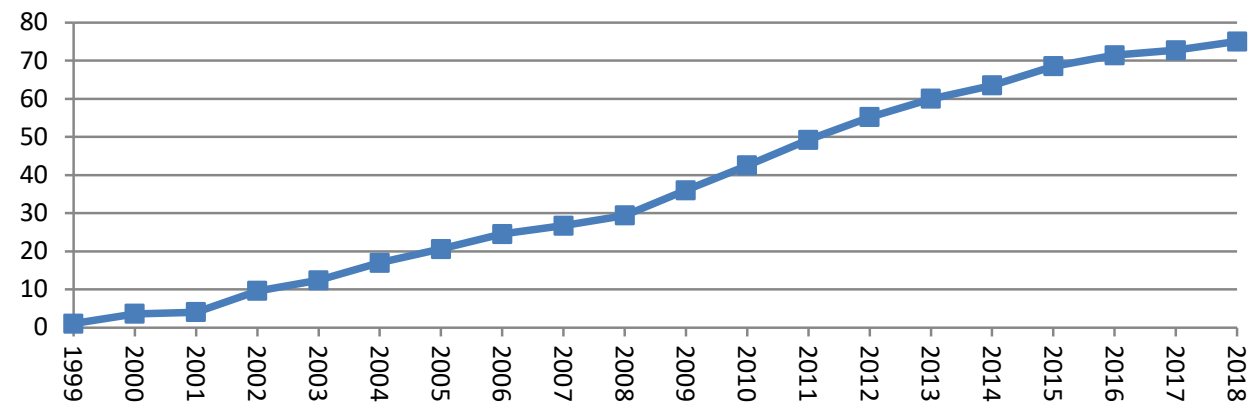

Figure 4. Dynamics of the share of internet users per 100 people in the Russian Federation for 1999-2018, \%

Note. Compiled by the author based on sources: [Federal State Statistics Service of the Russian Federation, 2020].

We note the positive growth dynamics of the share of internet users per 100 people in the Russian Federation for 1999-2018. Moreover, the crisis in the national economy, its post-crisis recovery and stagnation did not have a significant impact on the slowdown in the growth rate of the number of Internet users in Russia. We note that this factor has a positive effect in attracting FDI into the Russian economic system.

Unemployment rate (Unempl) is an important factor in attracting FDI to the recipient country since its high values lead to cheaper labor and the absence of transaction costs for hiring workers. Cheap labor is one of the key factors of attracting FDI by host countries, which is significantly affected by the unemployment rate (Melnyk, Kubatko, Pysarenko, 2014). On the other hand, recipient countries, attracting FDI and taking economic, as well as other exemptions for foreign investors, want to reduce its significance for the country`s population (Sergeev, Veretennikova, 2000).

Considering the characteristics of the factors influencing the attraction of FDI in the economy of the recipient country using the Russian Federation as an example, it is important to consider the dynamics of the share of unemployed from the economically active population in the state over the study period (Fig. 5).

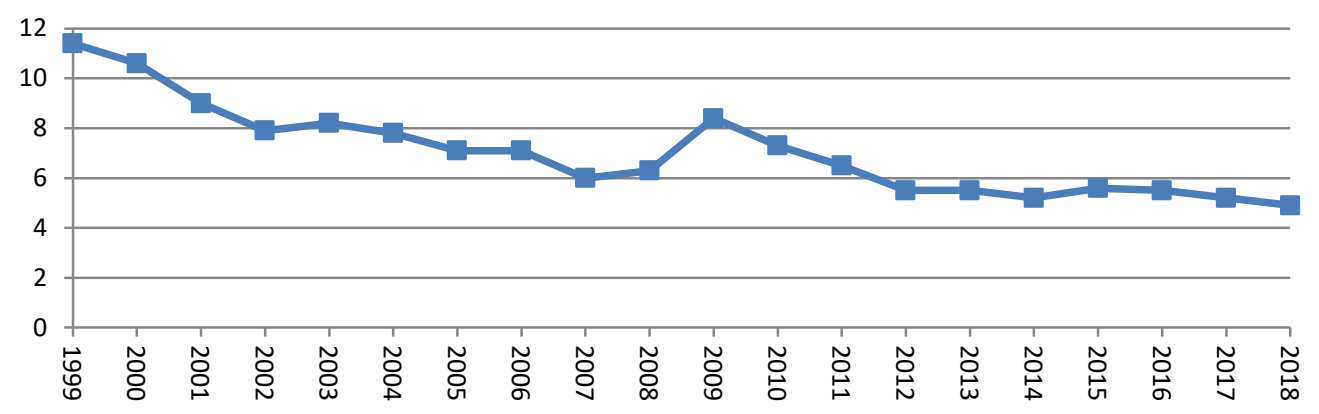

Figure 5. Dynamics of the share of unemployed from the economically active population in the Russian Federation for 1999-2018, \%

Note. Compiled by the author based on sources: [Federal State Statistics Service of the Russian Federation, 2020].

We note the positive dynamics of the percentage of unemployed in Russia over the study period $(-6.5 \%)$. Thus, we can argue that the task of reducing unemployment by attracting FDI is not the main task for the Russian economy. On the other hand, this situation is a disincentive for attracting FDI to the Russian Federation.

Given the increasing complexity of production and business operations in most business entities, such a component of the state's institutional environment as the percentage of the population with higher education (LFTE) is essential for foreign investors in the host country. A large number of people with higher education suggest that investors will be able to attract not only production and maintenance personnel but also management and scientific personnel to enterprises without additional transaction costs. Consider the situation in the Russian Federation with this factor in attracting FDI during the study period (Fig. 6). 


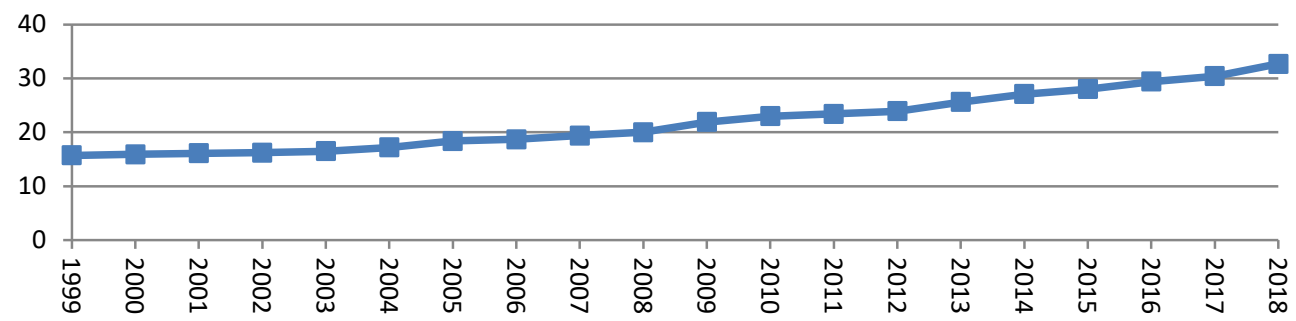

Figure 6. Dynamics of the share of people with higher education in the Russian Federation for 1999-2018,\%

Note. Compiled by the author based on sources: [Federal State Statistics Service of the Russian Federation, 2020].

We focus on the positive dynamics of the percentage of people with higher education from the entire population of Russia during the study period $(+17.0 \%)$. Moreover, the crisis manifestations in the national economy of the last decade did not affect the dynamics of the growth in the number of people with higher education. The given situation is a significant positive factor for attracting FDI into the Russian economy. On the other hand, the structure of the population in the areas of higher education and the shortage of working professions substantially level this positive aspect of attracting FDI in Russia.

One of the important aspects of attracting FDI in host countries, especially those that are developing their economic systems, is the attraction of new technologies and innovations to the national economy. Thus, an important factor to study is the share of high-tech exports in the total export (HTE). A high percentage of such exports indicate that the country has either received such investments or does not need them. Considering the dynamics of the share of high-tech exports in the total export of the Russian Federation for the study period (Fig. 7).

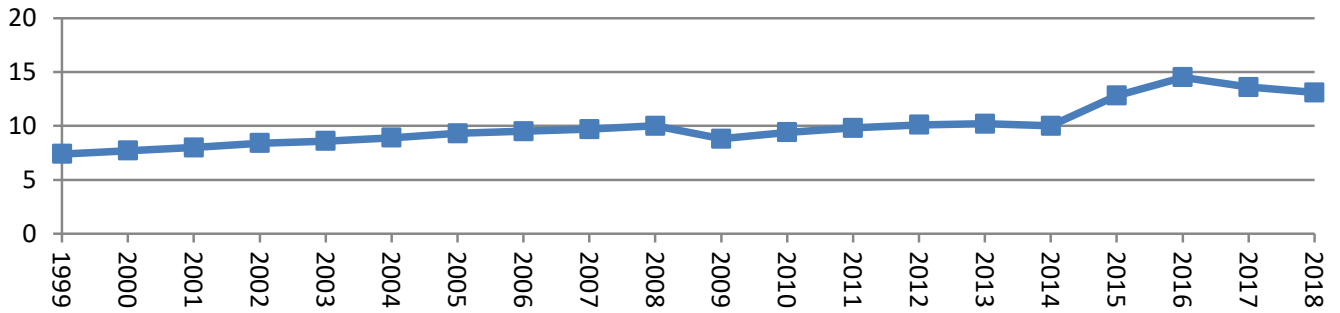

Figure 7. Dynamics of the share of high-tech exports in total exports of the Russian Federation for 1999-2018, \% Note. Compiled by the author based on sources: [Federal State Statistics Service of the Russian Federation, 2020].

On one hand, we note the positive growth dynamics of the share of high-tech exports in the total export of the Russian Federation over the study period $(+5.7 \%)$, and on the other hand, its low values during the years of the assessment. We focus on the negative trends regarding high-tech exports in 2017-2018. Thus, we can note that Russia requires the active attraction of FDI in the economic system to increase the level of used technologies and innovations.

The political component in the recipient country is important for foreign investors, which is proposed to include the product of the indices of economic freedom and state insolvency (inst). Consider these indices in relation to Russia over the study period (Fig. 8). We note that the state insolvency index will be given since 2005 when it began to be compiled.

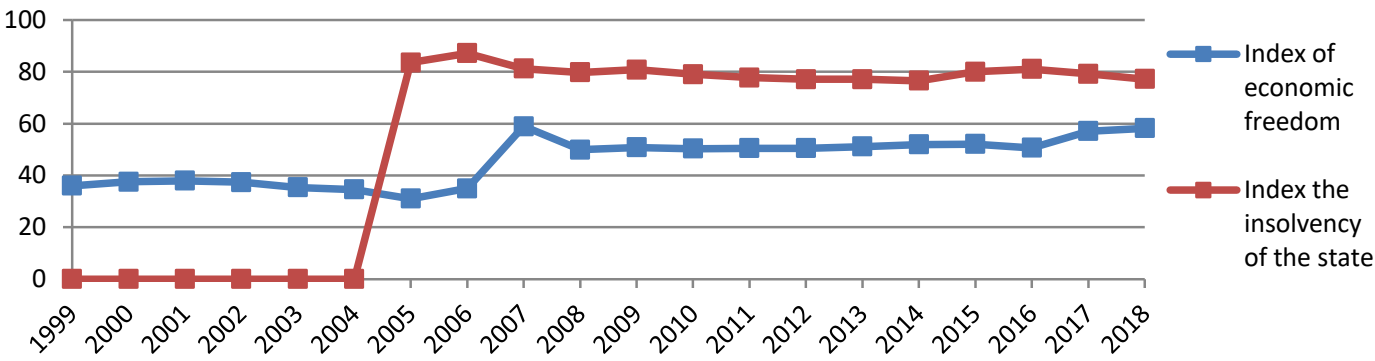

Figure 8. The dynamics of the indices of economic freedom, the insolvency of the state of the Russian Federation for 1999-2018

Note. Compiled by the author based on sources: [Heritage Foundation, 2020; The Fund for Peace, 2020]. 
Summing up the study, we can conclude that: according to the index of economic freedom, Russia throughout the study period belonged to non-free states; according to the state insolvency index, the Russian Federation for the entire period of the study belonged to the states with an increased warning. Thus, the above is not an encouraging factor in attracting FDI into the Russian economy and indicates critical problems in the development of the country's political system and its institutions of power.

When investing in FDI, foreign investors pay attention to international indices and ratings, where the country's ranking in terms of business conditions occupies a special place. The Ease of Doing Business Index attests to the quality and ease of regulating businesses, as well as the quality of protecting property rights in a particular country. Thus, in our study, this index can be attributed to both international and political factors, but it relates more to the international assessment of the country and the functioning of its economic system, which allowed it to be attributed to international factors. Consider the dynamics of the place of the Russian Federation in accordance with the Ease of Doing Business Index for the study period (Fig. 9). We note that the study will begin in 2006 when the rating started.

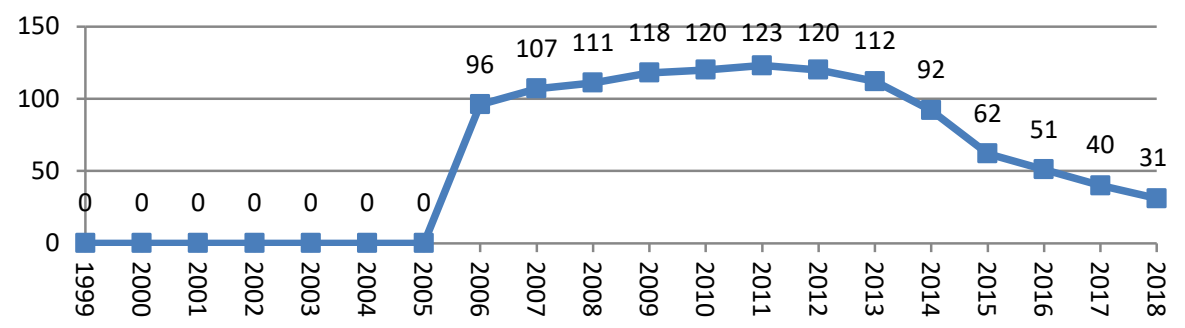

Figure 9. The dynamics of the place of the Russian Federation in accordance with the Ease of Doing Business Index for 1999-2018

Note. Compiled by the author based on sources: [The World Bank, 2020].

We note a sharp increase in place of Russia in accordance with the Ease of Doing Business Index, and its positive dynamics since 2011. The above is a positive factor for attracting FDI into the Russian economy. At the same time, the imposition of sanctions against the Russian Federation did not affect the downgrade of the country as part of the ease of doing business.

An important, albeit ambiguous, value for attracting FDI in a recipient country is the competitiveness of its economy. On one hand, the high competitiveness of the recipient country makes it easier to organize the export of goods (works, services) produced using FDI investment in business entities of this state. On the other hand, countries with an insufficient level of competitiveness of their economies face the need to attract FDI the most, which reduces the transaction costs of investors entering the economic system of such countries and increases their profits. To assess the competitiveness of the national economy, we consider it appropriate to use the Global Competitiveness Index. Consider the place of the Russian Federation in accordance with The Global Competitiveness Index for the study period (Fig. 10). The study will begin in 2005, the year the rating started.

We note the generally positive dynamics regarding the improvement of the competitiveness of the Russian economy over the study period. At the same time, the negative impact on the competitiveness of the Russian economic system of crisis phenomena in 2009 , which could only be overcome by 2014 , is visible. The economic crisis and the stagnation of the Russian economy in the period from 2014 to 2018 did not negatively affect the country's competitiveness. We note the generally favorable situation for attracting FDI into the Russian economy in the context of assessing its competitiveness.

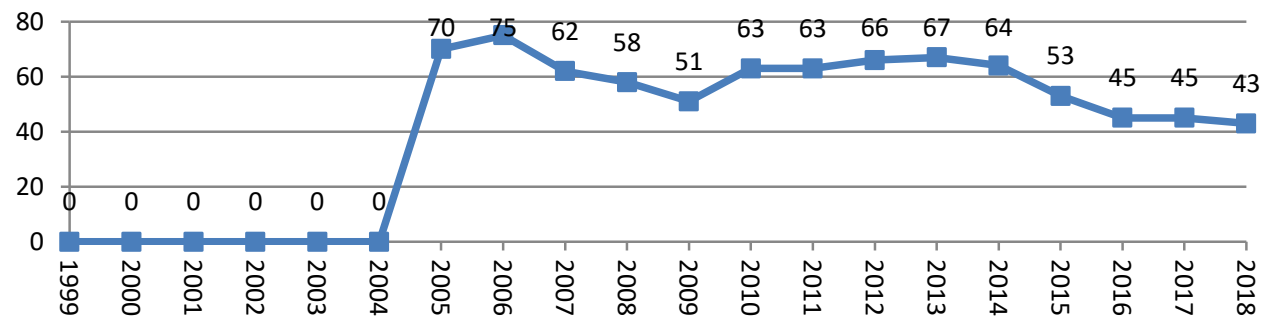

Figure 10. The dynamics of the place of the Russian Federation in accordance with The Global Competitiveness Index for 1999-2018

Note. Compiled by the author based on sources: [The World Economic Forum, 2020]. 
To attract foreign investors to the economy of the recipient country, the global FDI rating (GRFDI) is important. Investors can evaluate the popularity of investments in the host economy, as well as the dynamics of changes in the country's position over a certain period of time and make informed decisions regarding investment. Consider the place of the Russian Federation in the global ranking of FDI for the study period (Fig. 11).

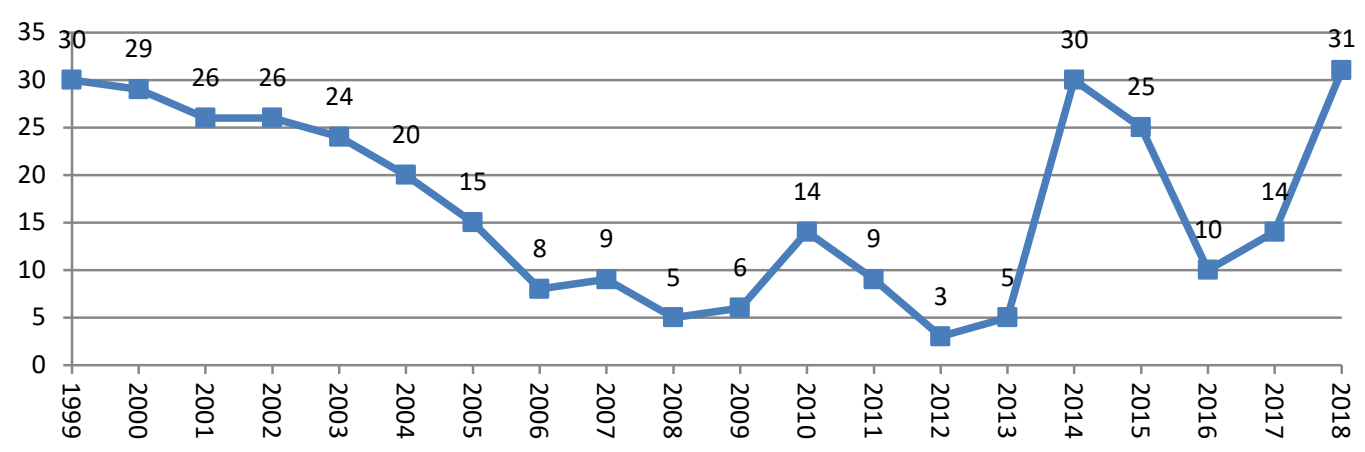

Figure 11. The dynamics of the place of the Russian Federation in the global ranking of FDI for 1999-2018 Note. Compiled by the author based on sources: [UNCTAD, 2020].

We note multi directional trends regarding the place of the Russian Federation in the global ranking of FDI over the study period. At the same time, there is a clear tendency to deteriorate the relations of foreign investors in the Russian economy since the period of the imposition of economic sanctions (2014-2018). These data indicate that the Russian economic system is not a priority for foreign investors, and the country should actively change its strategy of attracting FDI.

Foreign investors bringing FDI to the economy of the recipient country, monitor the rate of devaluation (revaluation) of the national currency, since a moderate devaluation brings additional benefits. In contrast, revaluation or a strong devaluation of the national currency carries negative aspects for FDI and, especially, for paid dividends to foreign investors. Consider the dynamics of the rate of devaluation (revaluation) of the Russian ruble over the study period (Fig. 12). (As a comparison base USD is taken).

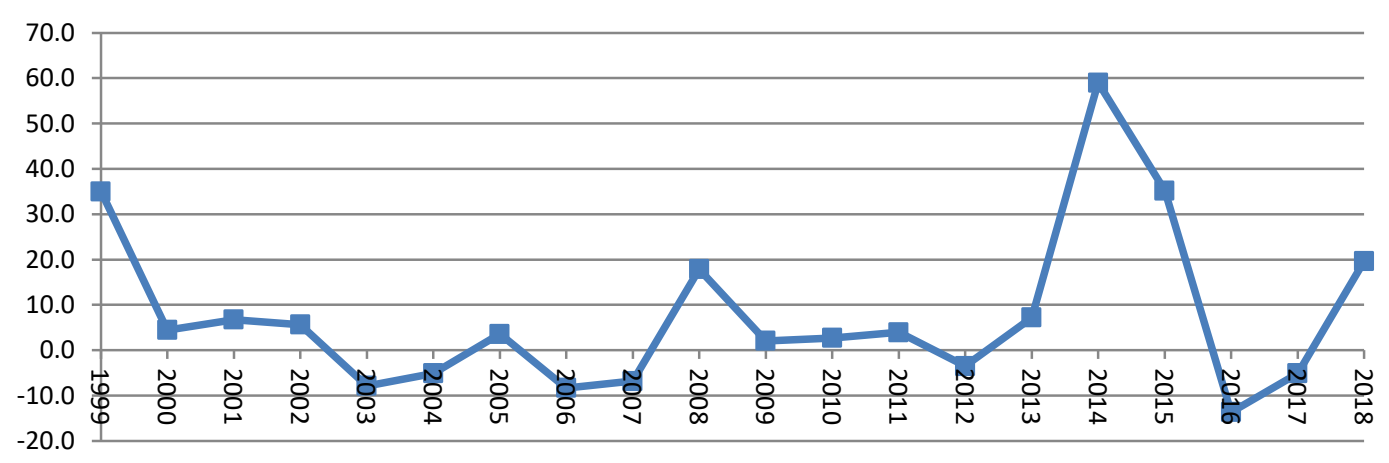

Figure 12. Dynamics of devaluation (revaluation) of the Russian ruble for 1999-2018 (against the USD), \% Note. Compiled by the author based on sources: [Central Bank of the Russian Federation, 2020].

We note the high volatility of the Russian ruble exchange rate, especially during periods of economic crisis, which makes this factor negative in relation to attracting FDI to the Russian economy.

Entering the recipient countries' markets, foreign investors are guided by the cost and profitability of investment resources in the economy of the host countries. Why is it important to study the growth rate of interest rates on investments . Let us consider such rates in relation to the Russian Federation for the study period (Fig. 13). 


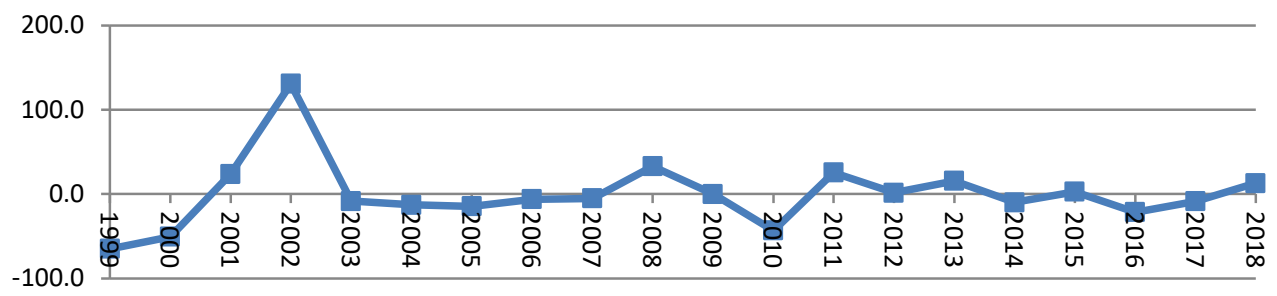

Figure 13. The dynamics of the growth rate of interest rates on investments in Russia for 1999-2018, \% Note. Compiled by the author based on sources: [Central Bank of the Russian Federation, 2020].

It should be noted that there is significant volatility in the deposit market in Russia, which significantly complicates the attraction of FDI in the country's economic system. Thus, we can argue that this factor is a stimulating factor for the Russian economy.

The level of the tax burden of business has a significant impact on attracting FDI. The high tax burden, which is a characteristic of economically developed countries, leads to an active search for countries with its low values so as to increase the profitability of the business. Consider the dynamics of the level of the tax burden of business in the Russian Federation for the study period (Fig. 14).

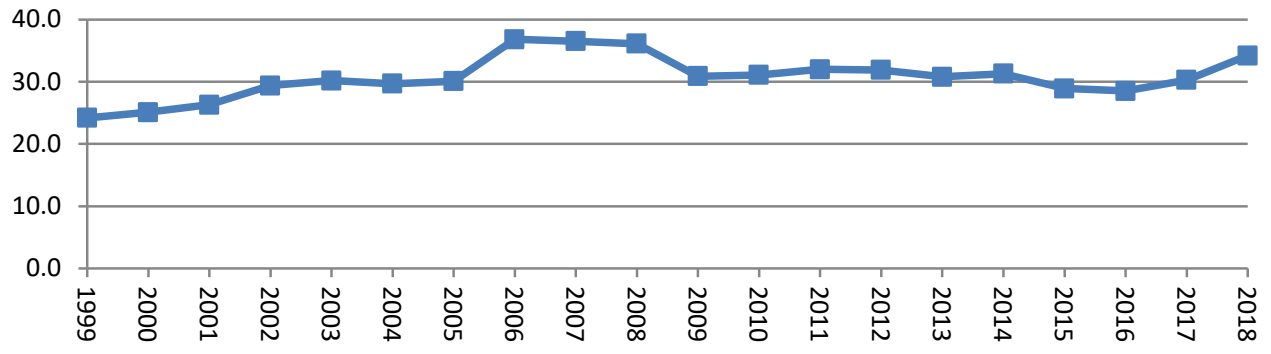

Figure 14. Dynamics of the level of the tax burden of business in the Russian Federation for 1999-2018, \% Note. Compiled by the author based on sources: [Federal State Statistics Service of the Russian Federation, 2020].

We note that, on one hand, there is a rather low level of the tax burden in Russia as compared with economically developed countries. On the other hand, its values are high, compared to most developing countries. Special attention should be paid to the negative trend of growth in the tax burden on business during the study period (+ $10 \%)$. The above indicates that the level of the tax burden on business is a factor with a negative impact on attracting FDI to the Russian economy.

Since a significant part of FDI goes to industry and the agricultural sector, an important factor for foreign investors, is the level of labor productivity in the recipient country. A sufficient level of productivity in the national economic system will form a sufficient supply of products (works, services) in potential sales markets. However, it should be noted that many developing countries and countries with economies in transition are actively attracting FDI, including with the aim of increasing labor productivity in the entire national economic system or its individual sectors. Hence, we can argue that the level of productivity in the host country is important, but not fundamental, from the point of view of foreign investors and their intentions to invest in the economy of the recipient state. Consider the level of labor productivity in Russia over the study period (Fig.15).

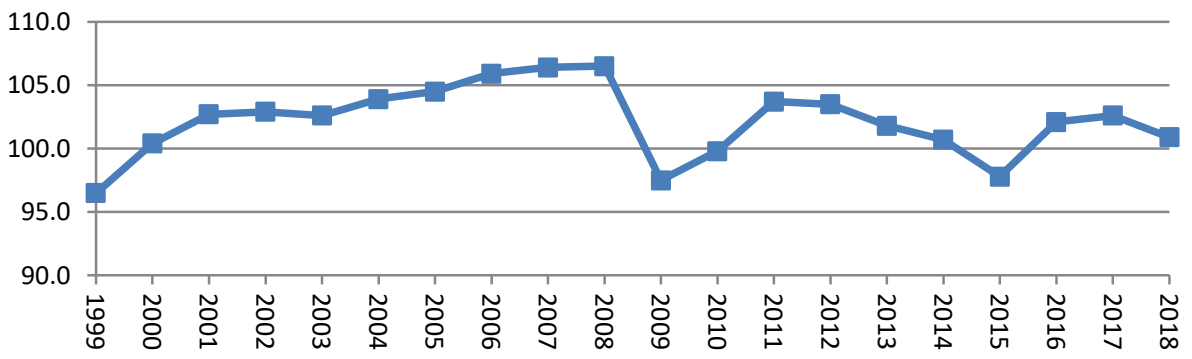

Figure 15. Dynamics of the level of labor productivity in the Russian Federation for 1999-2018, \% 
We note significant fluctuations in the level of labor productivity, which are associated with the development trends of the Russian economy. So, during the periods of economic growth, relatively high values of labor productivity growth in the Russian Federation were observed. At the same time, the crisis in the Russian economy led to sharp decreases in labor productivity. We note the negative changes in the level of labor productivity in 2017-2018, which is a stimulating factor in attracting FDI to the Russian economic system.

An essential aspect of attracting FDI into the economy of the recipient country is the difference between the interest rates on investments in this country and the international interest rates; the higher the difference is, the greater the desire of foreign investors to invest is. On the other hand, the large difference between the interest rates on investments in the host state and international interest rates indicates high investment risks, which significantly narrows the circle of investors for FDI. Regarding Russia, we note that, during the entire period of the study, there is a positive difference between interest rates on investments in the country's economy and international interest rates. At the same time, a tendency is clearly visible, during the years of crisis, this difference increased, and in the years of economic growth, it is decreased. We note the increase in the positive difference between interest rates on investments in the Russian economy and international interest rates in 20142018 (Federal State Statistics Service of the Russian Federation, 2020). The given situation, on one hand, indicates an increase in interest in investing in the Russian economy by foreign investors, and on the other, an increase in the risks of FDI investments in the Russian economic system.

Similar conclusions to those that were made above can be formed regarding the difference between the price of an investment in the host country and international prices. We note a positive difference throughout the study period regarding investments in the Russian Federation (Federal State Statistics Service of the Russian Federation, 2020). At the same time, problems with attracting FDI into the Russian economy, especially after the introduction of economic sanctions, indicate that this factor has not become a key factor for the growth of investment in the country.

Summing up the study, we find it necessary to consider the final values of the influence of all factors proposed for the study on the attraction of FDI in the Russian economy (Table 4). In this case, the "+" sign will indicate a positive influence of the factor, and the "-" sign will be negative, the "+/_" sign will be variable.

Table 4. Factors influencing the attraction of FDI in the Russian economy

$\begin{array}{cc}\text { Factor Name } & \text { Factor effect/ influence } \\ \text { GDPg - GDP growth rate } & - \\ \text { TOI - Trade openness index } \\ \text { Defl - GDP deflator }\end{array}$

Source: developed by the author.

After evaluating the data from Table 4, we can conclude that from seventeen identified factors influencing the attraction of FDI in the Russian economy: ten have a negative impact; three - positive; four are variable. Thus, we can argue that Russia needs a drastic change in the strategy of attracting FDI, taking into account the economic sanctions that apply against its economy and its individual actors. The above requires verification using economic and mathematical modeling. 


\subsection{Identification of the Differences between the Factors Influencing the Attraction of FDI in Developed and Developing Countries}

The economic goals set by economically developed and developing countries lead to significant differences between the factors influencing the attraction of FDI in these two large groups of countries (Lipsey, 2002; Maza, Villaverde, 2015). Moreover, economically developed countries often act as donors, and developing recipients in relation to FDI. Hence, we consider it possible to give a comparative characterization of the factors influencing the attraction of FDI to develop and developing countries (Table 5).

Table 5. Comparative characteristics of factors influencing FDI in developed and developing countries

\begin{tabular}{ccc}
\hline Factors & Developed countries & Developing countries \\
\hline Development of the national economy & + & - \\
Inflation & - & + \\
National currency exchange rate & - & + \\
Infrastructure development & + & + \\
The effectiveness of government institutions & - & + \\
Corruption & + & + \\
Political instability & + & + \\
Competitiveness of the national economy & + & + \\
Workforce quality & + & - \\
Percentage of population with higher education & + & + \\
Level of innovation activity & + & + \\
Tax burden & + & + \\
Business Conditions & + & + \\
Investment income & + & + \\
Unemployment cost & + & + \\
Labor cost & + & +
\end{tabular}

Note. Compiled by the author based on sources: [Fabry \& Zeghni, 2006; Amal, Tomio, \& Raboch, 2010; Solomon, 2011; Tintin, 2013; Goblik \& Feer, 2016; Shmyhol \& Pavlyuk, 2017].

We note a significant difference between the factors influencing the attraction of FDI in developed and developing countries. Moreover, for economically developed countries, economic and institutional factors are of particular importance, while for developing countries, often economic factors are of secondary importance, and the emphasis is on political, international, and institutional factors.

Summing up the study of the factors influencing the attraction of FDI in the economy of the host state, we note: a substantial scientific discussion regarding their identification and characteristics; differences between factors for developed and developing countries; problems of the Russian Federation in the framework of attracting FDI into its economy, which require solutions based on the use of economic and mathematical modelling.

\section{Analysis and Forecasting of FDI in the Russian Economy}

The Russian economy, in recession and under the influence of economic sanctions, is generating a steady demand for FDI. In these conditions, we consider it appropriate to analyze FDI in the Russian economy over the past twenty years (1999-2018).

An important aspect in terms of assessing the impact of FDI on the Russian economy is the size of FDI per capita; analyzed in Table 6. 
Table 6. Analysis of the dynamics of the inflow of FDI in the economy, dynamics of the population, and the size of FDI per inhabitant in Russia from 1999 to 2018

\begin{tabular}{cccc}
\hline Years / Indicators & FDI, billion USD & Total population, million people & FDI per inhabitant in USD \\
\hline 1999 & 9.6 & 147.2 & 65.2 \\
2000 & 11.0 & 146.6 & 75.0 \\
2001 & 14.3 & 146.0 & 97.9 \\
2002 & 19.8 & 145.3 & 136.3 \\
2003 & 29.7 & 144.6 & 205.4 \\
2004 & 40.5 & 144.1 & 281.1 \\
2005 & 53.7 & 143.5 & 374.2 \\
2006 & 55.1 & 143.1 & 385.0 \\
2007 & 120.9 & 142.8 & 846.6 \\
2008 & 103.8 & 142.7 & 727.4 \\
2009 & 81.9 & 142.8 & 573.5 \\
2010 & 114.7 & 142.9 & 802.7 \\
2011 & 190.6 & 143.0 & 1332.9 \\
2012 & 154.5 & 143.2 & 1078.9 \\
2013 & 170.2 & 143.5 & 1186.1 \\
2014 & 22.0 & 143.9 & 152.9 \\
2015 & 6.9 & 144.1 & 47.9 \\
2016 & 32.5 & 144.3 & 225.2 \\
2017 & 28.6 & 144.5 & 197.9 \\
2018 & 8.8 & 144.5 & 60.9
\end{tabular}

Note. Compiled by the author based on sources: [Federal State Statistics Service of the Russian Federation, 2020; Knoema, 2020].

An analysis of the dynamics of FDI inflows into the economy, population dynamics, and the size of FDI per one resident of Russia allows us to draw the following conclusions:

- Amid a decrease in the size of FDI and the total population, we note a reduction in the size of FDI per one resident of the Russian Federation during the study period by 4.3USD - from 65.2 USD in the year 1999 to 60.9 USD in the year 2018 (-6.62\%);

- One can clearly distinguish a strong influence on the size of FDI per citizen in the crisis. So, after the growth of FDI per capita from 1999 to 2007, in 2008-2009, there was a significant decrease in this size, a period of significant growth in 2010-2011, a period of volatility in 2012-2013 and a sharp decrease in the indicator in 2014 -2018 with substantial fluctuations over the years;

- We pay attention to the critically small values of the FDI size in the year 2018 (the second minimum value after the year 2015), which indicates a significant impact on the size of the indicator, not only because of the problems in the Russian economy, but also because of the economic sanctions against the state.

Assessing the impact of FDI on the Russian economy, it is essential to assess the net inflow, the net outflow of FDI, as well as their balance over the study period (Fig. 16).

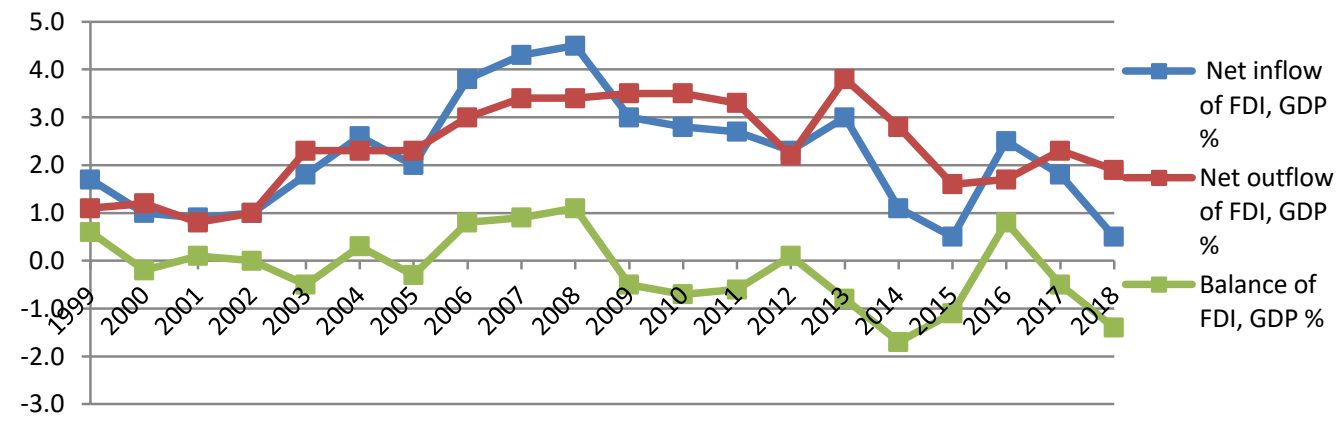

Figure 16. Dynamics of net inflow, the net outflow of FDI, as well as their balance in Russia from 1999 to 2018 , GDP \%

Note. Compiled by the author based on: [Federal State Statistics Service of the Russian Federation, 2020; Knoema, 2020]. 
After analyzing the dynamics of the net inflow, the net outflow of FDI, as well as their balance in Russia over the study period, we can note that:

- During the twenty years of research period - the positive balance regarding FDI in the Russian Federation was only recorded in eight years; in one year, it was equal to zero; and in eleven years the balance was negative;

- For the period from 2009 to 2018 years (the last ten years of the study and covering two economic crisis), the balance was positive only twice (2012, 2016 years);

- The country's economic system is experiencing significant problems attracting FDI against the backdrop of crisis and the introduction of economic sanctions, reflecting mainly in the outflow of FDI from the state.

Summing up the analysis, we note the significant problems of the Russian Federation attracting FDI in recent years (2014-2018), the presence of a set of strategic and tactical measures to increase the attraction of FDI in the country's economy, as evidenced: periods of growth of FDI per capita (Table 5), as well as a surplus in relation to such investments (Fig. 16). Of particular importance here is the situation in the year 2015-2018, when the positive trend of 2015-2016 changed into negative in 2017-2018, which requires further study of the situation in order to understand how effective the measures taken are in attracting FDI in the Russian economy, and prevalence of negative or positive factors. Under these conditions, we consider it necessary, to use the regression analysis, as well as the software capabilities of the Stata 7.0 computer program, to forecast the balance of FDI inflows into the Russian economy (Fig. 17), where the determination coefficient) will be an element of verification of the regression function.

Within the framework of forecasting, three regression functions are obtained:

1). Linear:

$$
y=0,060 x+0,4563
$$

Moreover, the coefficient of determination $\left(\mathrm{R}^{2}\right)$ will be equal to 0.2114 , which indicates a low degree of tightness of the connection (correlation) between the totality of influence factors (x) and the size of the FDI balance in the Russian economy (y).

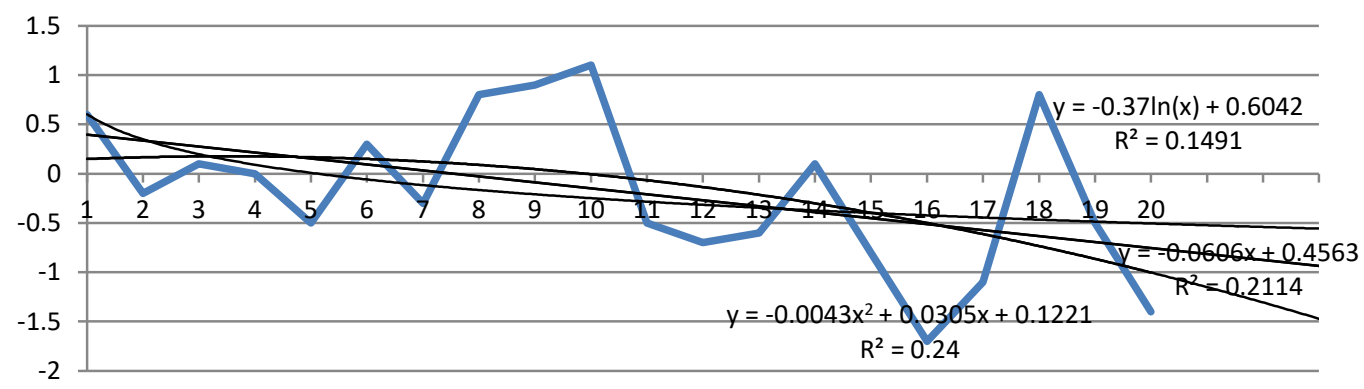

Figure 17. Forecast the balance of FDI in the Russian economy (for three years), GDP\%

Source: developed by the author.

2). Logarithmic:

$$
\mathrm{y}=-0,37 \ln (\mathrm{x})+0,6042
$$

Moreover, the coefficient of determination $\left(\mathrm{R}^{2}\right)$ will be equal to 0.9491 , which indicates a high degree of tightness of the connection (correlation) between the totality of influence factors ( $\mathrm{x}$ ) and the size of the FDI balance in the Russian economy (y).

3). Polynomial:

$$
\mathrm{y}=-0,0043 \mathrm{x}^{2}+0,0305 \mathrm{x}+0,1221
$$

Moreover, the coefficient of determination $\left(\mathrm{R}^{2}\right)$ will be equal to 0.24 , which indicates a low degree of tightness of the connection (correlation) between the totality of influence factors (x) and the size of the FDI balance in the Russian economy (y).

Based on the forecast, we note the need for its implementation based on the logarithmic regression function (the determination coefficient is the largest of all regression functions selected for forecasting and approaches unity). At the same time, we note the continuation of the negative trend during the forecast period. 
Thus, we can conclude significant problems regarding the attraction of FDI in the Russian economy, especially in the period between 2014-2018 years. Moreover, the forecast for the next three years confirmed negative trends in this area. Based on the findings, we can argue that Russia requires a significant change in its strategy for attracting FDI, identifying key factors influencing the flow of FDI, and leveling the negative impact of these factors.

\section{Discussion}

The study of the factors influencing the attraction of FDI in the economy of the host state is an important component of the economic development of the countries around the world, especially the developing ones. Under these conditions, the problem of identifying and evaluating the factors influencing the attraction of FDI in the Russian economic system is of considerable interest, which requires testing a number of hypotheses.

Critical literary analysis has confirmed the first hypothesis of scientific research. Thus, we can state that, in the context of identifying the factors influencing the attraction of FDI in the economy of the recipient country, it is necessary to rely on the representation of the largest possible group of factors in order to cover all the key ones.

Identification and assessment of the factors influencing the attraction of FDI in the Russian economy allow us to state that negative factors prevail, which refutes the second hypothesis of scientific work.

The use of a comparative assessment made it possible to prove the existence of significant differences between the factors influencing the attraction of FDI in developed and developing countries and to confirm the third hypothesis of this study.

The hypothesis that the influx of FDI into the Russian economy demonstrates predominantly positive dynamics has not been confirmed. The forecasting also showed the presence of a negative trend in the next three years following the year of the end of the study.

Given the above, we can note that the goal of the study, set at the beginning of the work is achieved. The key value of the article is to identify a combination of the main factors influencing FDI inflows to Russia, as well as assessing the direction of influence of each of the identified factors. In this regard, we can highlight certain limitations in the application of the results of this article, namely: the need to verify the adequacy of the number of identified factors based on economic and mathematical modeling and empirical analysis; the need to identify correlations between identified factors based on economic and mathematical modeling and empirical analysis. At the same time, the formulated limitations do not reduce the scientific and practical value of this article and characterize to a greater extent, the prospects for further scientific research.

\section{Conclusion}

Russia, being in the tough economic conditions associated with the recession of the economy and the impact of economic sanctions, need to intensify the influx of FDI and transform its national investment strategy. In such circumstances, an important aspect of the changes is the identification and characterization of the main factors influencing the attraction of FDI in the Russian economy. At the same time, identifying the direction of influence of such factors on the economic system of the recipient country (positive or negative) is of particular importance, which will make it possible to pay attention to eliminating or reducing the influence of negative factors in the future.

We note that from the seventeen identified factors of attracting FDI to the economy of the Russian Federation, only three have a positive impact on it (the number of Internet users per 100 people; the country's rating in terms of business conditions; the country's global competitiveness index), four have a neutral effect (percentage of population with higher education; the country's global FDI rating; difference between interest rates on investments in Russia and international interest rates; difference between price investments in Russia and international prices). At the same time, ten factors of attracting FDI into the Russian economy have a negative impact: the growth rate of GDP; trade openness index; GDP deflator; unemployment rate; the share of high-tech exports in total exports; the product of indices of economic freedom and state insolvency; rates of devaluation (revaluation) of the Russian ruble; growth rates of interest rates on investments; business tax burden; labor productivity level. In such conditions, identification and characterization of the main factors influencing the attraction of FDI in the Russian economy will improve the national investment strategy and increase the level of stimulation of FDI in the Russian economic system.

The practical implementation of the proposals and conclusions of this article should be considered in the context of their importance for stimulating the influx of FDI into the Russian economy and creating a long-term positive balance of FDI in the Russian economic system. At the same time, to increase the influx of FDI into Russia, the country should develop and implement a set of long-term measures, which should include: amendment of 
legislation; reform of government and local self-government; increasing transparency of the national economy; reducing the impact of corruption on economic relations in the state; decrease in the role of the shadow economy; increasing the protection of the rights and property of foreign investors; institutional reform in the context of reducing the number of "institutional traps"; the formation of clear, understandable and the same rules for foreign investors.

Prospects for further research based on and using the scientific results of the study consist of the need to form the optimal number of identified factors based on economic and mathematical modeling and empirical analysis.

\section{References}

Amal, M., Tomio, B., \& Raboch, H. (2010). Determinants of Foreign Direct Investment in Latin America. GCG Georgetown University-UNIVERSIA, 4(3), 116-133. http://doi10.3232/gcg.2010.v4.n3.07

Asiedu, E., \& Esfahani, H. S. (1998). Ownership Structure in Foreign Direct Investment Projects. Department of Economics, University of Illinois. https://doi.org/10.2139/ssrn.152570

Azzimonti, M., \& Sarte, P. (2007). Barriers to Foreign Direct Investment Under Political Instability. Economic Quarterly, 93(3), 287-315.

Бандурка, А. М., Носова, О. В., \& Носова, Т. Ю. (2016). Взаимовлияние прямых иностранных инвестиций и экономического роста. [The interaction of foreign direct investment and economic growth.] Европейские перспективы, 1, 5-13.

Bilawal, M., Ibrahim, M., Abbas, A., Shuaib, M., Ahmed, M., Hussain, I., \& Tehreem, F. (2014). Impact of Exchange Rate on Foreign Direct Investment in Pakistan. Advances in Economics and Business, 2(6), 223231. https://doi.org/10.13189/aeb.2014.020602.

Brainard, S. L. (1997). An Empirical Assessment of the Proximity Concentration Tradeoff between Multinational Sales and Trade. American Economic Review, 87(4), 520-544.

Buchanan, B. G., Le, Q. V., \& Rishi, M. (2012). Foreign direct investment and institutional quality: Some empirical evidence. International Review of Financial Analysis, 21, 81-89. https://doi.org/10.1016/j.irfa.2011.10.001

Busse, M., Hefeker, C., \& Nelgen, S. (2013). Foreign Direct Investment and Exchange Rate Regimes. Economics Bulletin, 33(1), 843-858. https://doi.org/10.2139/ssrn.1593002

Buthe, T., \& Milner, H. (2008). The Politics of Foreign Direct Investment into Developing Countries: Increasing FDI through International Trade Agreements. American Journal of Political Science, 52(4), 741-762. https://doi.org/10.1111/j.1540-5907.2008.00340.x

Данг, М. А. (2016). Пути и методы активизачии привлечения прямых иностранных инвестиций в странах АСЕАН в условиях глобализаџии (на примере СРВ [Ways and methods of activating the attraction of foreign direct investment in ASEAN countries in the context of globalization (on the example of SRV)] (Диссертация на соискание учёной степени кандидата экономических наук, Государственный университет управления, Москва, Россия). Retrieved from https:/guu.ru/files/dissertations/2016/03/dang_m_a/autoreferat.pdf

Демченко, А. Г. (2011). Problems of attracting foreign investment in the economy of the Republic of Belarus. Retrieved from http://elib.bsu.by/bitstream/123456789/94295/1/218-223\%202_67.pdf

Драпкин, И. М., Мариев, О. С., Чукавина, К. В. (2015). A quantitative assessment of the potential for import and export of foreign direct investment in the Russian economy based on the gravitational approach. Журнал Новой экономической ассоциации, 4(28), 75-95.

Fabry, N., \& Zeghni, S. (2006). How former communist countries of Europe may attract inward foreign direct investment? A matter of institutions. Communist and Post-Communist Studies, 39, 201-219. https://doi.org/10.1016/j.postcomstud.2006.03.006

Fan, J. P. H. (2009). Institutions and Foreign Direct Investment: China versus the Rest of the World. World Development, 37(4), 852-865. https://doi.org/10.1016/j.worlddev.2008.07.016

Federal State Statistics Service of the Russian Federation. (2019). Statistical Information. Retrieved from http://www.gks.ru

Галенкова, А. Д., Мариев, О. С., \& Чукавина, К. В. (2018). Эконометрическое моделирование притока прямых иностранных инвестиций в развивающиеся страны [Econometric modeling of foreign direct 
investment inflows to developing countries.] Журнал Экономической теории, 2(18), 345-349. https://doi.org/10.31063/2073-6517/2018.15-2.19

Гоблик, В. В., \& Феер, А. Е. (2016). Детерминанты притока прямых иностранных инвестиций в развивающиеся страны.[Determinants of the inflow of foreign direct investment in developing countries.] Новое слово в науке: Nерспективы развития: материалы VII Междунар. науч.-практ. конф., 225227.

Gokalp, M. F., \& Yildirim, A. (2016). Institutions and Economic Performance: A Review on the Developing Countries. Procedia Economics and Finance, 38, 347-359. https://doi.org/10.1016/S2212-5671(16)30207-6

Горбунова, О. А. (2018). Привлечение прямых иностранных инвестиций в российскую экономику в условиях действия санкций.[Attracting foreign direct investment in the Russian economy under the conditions of sanctions.] Российское предпринимательство, 8(19), 2185-2200. https://doi.org/10.18334/rp.19.8.39261

Heritage Foundation. (2020). The Index of Economic Freedom. Retrieved from https://www.heritage.org/index

Knoema. (2019). Statistical Information. Retrieved from https://knoema.ru/atlas

Koboekae, T. (2012). The impact of political risk on foreign direct investment decisions by South African multinational corporations. University of Pretoria. Retrieved from https://repository.up.ac.za/handle/2263/30613

Квашнина, И. А. (2015). Приток капитала в Россию в условиях санкций.[ Capital inflow to Russia under sanctions.] Российский внешнеэкономический вестник, 11, 3-12.

Lipsey, R. E. (2002). Home and host country effects of FDI. NBER Working Paper, 9293: 78. https://doi.org/10.3386/w9293

Лузгина, А. (2016). Национальные особенности и международный опыт привлечения прямых иностранных инвестиций. [National features and international experience in attracting foreign direct investment.] Банковский вестник, Июнь, 21-29.

Makoni, P. L. (2014). Factors influencing the attraction of foreign direct investment and foreign portfolio investment into African economies. Corporate Ownership \& Control, 11(4), 203-213. https://doi.org/10.22495/cocv11i4c1p5

Maza, A., \& Villaverde, J. (2015). The determinants of inward foreign direct investment: Evidence from the European region. International Business Review, 24, 209-223. https://doi.org/10.1016/j.ibusrev.2014.07.008

Melnyk, L., Kubatko, O., \& Pysarenko, S. (2014). The impact of foreign direct investment on economic growth: case of post-communism transition economies. Problems and Perspectives in Management, 12(1), 17-24.

Mohamed, A., Bruno, T., \& Henrique R. (2010). Determinants of Foreign Direct Investment in Latin America. CGC Georgetown University, 4(3), 116-133. https://doi.org/10.3232/GCG.2010.V4.N3.07.

Сергеев, И. В., Веретенникова, И. И. (2000). Организация и финансирование инвестиций [Organization and financing of investments.] Москва: Финансы и статистика.

Щетинина, Е. Д., \& Хамдан, М. (2018). Детерминанты прямых иностранных инвестиций в принимающих странах - ситуация Сирии. [The determinants of foreign direct investment in host countries - the situation

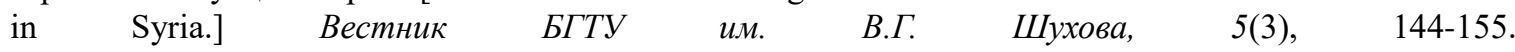
https://doi.org/10.12737/article_5af5a7353de584.18814479

Schneider, F., \& Frey, B. (1985). Economic and Political Determinants of Foreign Direct Investment. World Development, 13(2), 161-175. https://doi.org/10.1016/0305-750X(85)90002-6

Шмыголь, Н., \& Павлюк, Т. (2017). Слияния и поглощения как разновидность внешнеэкономической деятельности в контексте привлечения прямых инвестиций. [Mergers and acquisitions as a kind of foreign economic activity in the context of attracting direct investment.] Менеджмент $u$ предпринимательство: Мренды развития, 2(02), 49-56.

Solomon, E. M. (2011). Foreign direct investment, host country factors and economic growth. Ensayos Revista de Economía (Ensayos Journal of Economics), 1(30), 41-70.

The Fund for Peace. (2020). The Fragile States Index. Retrieved from https://fundforpeace.org/2019/04/10/fragile-states-index-2019

The World Bank. (2020). Doing Business. Retrieved from https://www.doingbusiness.org 
The World Bank. (2020). Trade. $\quad$ Retrieved $\quad$ from https://data.worldbank.org/indicator/NE.TRD.GNFS.ZS?locations=RU

The World Economic Forum. (2020). The Global Competitiveness Report. Retrieved from https://www.weforum.org/reports/global-competitiveness-report-2019.

Tintin, C. (2013). The determinants of foreign direct investment inflows in the Central and Eastern European Countries: The importance of institutions. Communist and Post-Communist Studies, 46, 287-298. https://doi.org/10.1016/j.postcomstud.2013.03.006

Tobin, J., \& Rose-Ackerman, S. (2005). Foreign Direct Investment and the Business Environment in Developing Countries: The Impact of Bilateral Investment Treaties. https://doi.org/10.2139/ssrn.557121

Третяк, Н. Н. (2013). Факторы формирования инвестиционного климата в Украине.[Factors in the formation of the investment climate in Ukraine.] Финансовый Nростор, 3, 165-170.

Центральный банк Российской Федерации. (2020). Статистические данные [The Central Bank of the Russian Federation (2020). Statistical data.] Retrieved from https://www.cbr.ru/statistics.

UNCTAD. (2020a). Country Fact Sheets 2019. Retrieved from https://unctad.org/en/Pages/DIAE/World\%20Investment\%20Report/Country-Fact-Sheets.aspx

UNCTAD. (2020b). World Investment Report, 2019. Retrieved from https://unctad.org/en/PublicationsLibrary/wir2019_en.pdf

\section{Copyrights}

Copyright for this article is retained by the author(s), with first publication rights granted to the journal.

This is an open-access article distributed under the terms and conditions of the Creative Commons Attribution license (http://creativecommons.org/licenses/by/4.0/). 